\title{
Effect of Integrated Nutrient Management on Growth and Yield of Maize (Zea mays L.)
}

\author{
C.N. Iniya Ponmozhi, Rabindra Kumar*, Yasin Abrar Baba and \\ Ganta Mallikarjuna Rao
}

Department of Agronomy, Suresh Gyan Vihar University, Jaipur, Rajasthan-302017, India

*Corresponding author

\section{A B S T R A C T}

\section{Keywords}

RDF, Maize, Vermicompost, FYM, Zinc and Yield

Article Info

Accepted:

30 October 2019

Available Online:

10 November 2019
The study entitled Effect of Integrated Nutrient Management on Growth and Yield of Maize (Zea mays L.) was conducted at Agricultural Research Farm, School of Agriculture, Suresh GyanVihar University, Jagatpura, Jaipur, during Kharif season 2018. The experiment was laid out in Randomized Block Design (RBD) with Three replication comprising Ten integrated nutrient management treatments viz. 100\% RDF $\left(\mathrm{T}_{1}\right), 50 \% \mathrm{RDF}$ $\left(\mathrm{T}_{2}\right), 100 \% \mathrm{RDF}+$ Vermicompost $\left(\mathrm{T}_{3}\right), 50 \% \mathrm{RDF}+$ Vermicompost $\left(\mathrm{T}_{4}\right), 100 \% \mathrm{RDF}+$ FYM $\left(\mathrm{T}_{5}\right), 50 \% \mathrm{RDF}+\mathrm{FYM}\left(\mathrm{T}_{6}\right), 50 \% \mathrm{RDF}+25 \%$ Vermicompost $+25 \%+\mathrm{FYM}+25 \mathrm{~kg}$ $\mathrm{ZnSo}_{4}\left(\mathrm{~T}_{7}\right), 50 \% \mathrm{RDF}+50 \%$ Vermicompost $+50 \% \mathrm{FYM}\left(\mathrm{T}_{8}\right), 100 \% \mathrm{RDF}+25 \%$ Vermicompost $+25 \%$ FYM $+25 \mathrm{~kg} \mathrm{ZnSo}_{4}\left(\mathrm{~T}_{9}\right)$ and $100 \% \mathrm{RDF}+50 \%$ Vermicompost + $50 \%$ FYM $\left(\mathrm{T}_{10}\right)$. On the basis of results revealed that among ten treatment $100 \% \mathrm{RDF}+$ $25 \%$ Vermicompost $+25 \% \mathrm{FYM}+25 \mathrm{~kg} \mathrm{ZnSo}_{4}\left(\mathrm{~T}_{9}\right)$ is significantly recorded maximum growth parameters like plant height $(\mathrm{cm})$, Leaf area index, Dry matter accumulation , Crop growth rate and yield parameters grain yield, Stover yield and Harvest index.

\section{Introduction}

Maize (Zea mays L.) is one of the most important cereal crop of the world agricultural economy as food, feed and industrial raw material, which ranked third largest cereal following rice and wheat respectively. Due to its high yield potential, it is called 'queen of cereals'. India, it is grown over 4 per cent of the net area sown and it is cultivated in an area of $8.69 \mathrm{M}$ ha with annual production and growth of $21.81 \mathrm{mt}$ and $3.6 \%$, respectively (Agricultural statistics at In a glance 2017).
Majorly the poor management of fertilizer has key role to play in obtaining low yield productivity, so in order to achieve optimum crop productivity management of nutrients through judicious application of organic sources (FYM, Vermicompost, manures, biofertilizers, etc.) and micronutrient are required furthermore, the fertilize management is one of the most important factors that influence the growth and yield of maize crop. (Ghaffari, et al., 2011). The application of chemical fertilizer can change the soil $\mathrm{pH}$, upset beneficial microbial 
ecosystem, increase pest and even contribute to the release of greenhouse gases. Therefore, under this situation, judicious use of integrated nutrient management is best alternatives for sustainable crop productivity while maintain soil fertility status in maize and other cereal based cropping system. This ultimately improves crop yield. The available quantity of animal excreta and crop residues cannot meet the country's requirements for crop production. Therefore, maximizing the usage of organic waste and combining it with chemical fertilizers and biofertilizer in the form of integrated manure appear to the best alternative (Guldur et al., 2015). Organic manures such as farmyard manure and vermicompost are important components of integrated nutrient management. Organic manures supply the traces amount of micronutrients, which are generally not supplied by the farmers as straight fertilizers. Organic farming is, therefore, the only remedy, which should be encouraged in order to lower down the cost of inputs and to improve soil health. The use of organic manures like FYM and Vermicompost not only helps to maintain the soil productivity by improving the physico-chemical properties of soil but also improves the efficiency of applied chemical fertilizers. It counteracts the ill effects of chemical fertilizers applied to the soil by way of reducing chemical toxicity to the microbes and thereby favours their growth. Besides this, organic manure improves the water holding capacity and cation exchange capacity of the soil, which results into smooth supply of nutrients to the crop plants and finally results into profitable yields. Zinc also plays a very important role in plant better growth, metabolic functions and also in increase protein content in grain because it helps in protein synthesis in grain. Zinc is also increases the plumpness of grain which results better yield of maize crop. Therefore, the present study was executed to evaluate the effect of integrated nutrient management on the growth and yield of maize crop.

\section{Materials and Methods}

A field experiment was conducted at Agriculture Research Farm, Suresh GyanVihar University during Kharif seasons of year 2018. The experiment laid out in randomized block design with three replicated. The total treatment combinations were Ten. The experimental site was situated at $26.9^{0}$ North latitude and $75.7^{0}$ East longitude with average rainfall $546.2 \mathrm{~mm}$. The soil of experimental field was Sandy loamy soil normal $\mathrm{pH}$ (8.48), organic carbon (0.71), low in NPK $(0.0,8.0,10.0)$. The field was ploughed and given pre-sowing irritation. After the preparatory tillage, field was divided into 30 different plots of $4 \mathrm{~m} \times 5 \mathrm{~m}$ size. The pretreated seed of variety K-25 hybrid maize (Kanchan Gangabrand) were sown by dibbling method in between the rows by using maize seed at the rate of $25 \mathrm{~kg} / \mathrm{ha}$ with a spacing of $60 \times 30 \mathrm{~cm}$ on 27 July, 2018. RDF (Recommended dose of fertilizer) of NPK for Maize is $150,75,75 \mathrm{~kg} / \mathrm{ha}$ and $\mathrm{ZnSo}_{4}$ is 25 $\mathrm{kg} / \mathrm{ha}$. Applied 1/3 N and full of dose P2O5, $\mathrm{K} 2 \mathrm{O}$ and $\mathrm{ZnSo}_{4}$ as basal and remaining dose of $\mathrm{N}$ was applied as topdressing in two split at knee high stage and at Pre-tasselling stage. The amount of vermicompost and FYM was applied at per treatment wise. The field was kept free from weeds by manual hoeing. Plant protection measures and irrigations whenever required were provided in same manner for all the treatments. Regular biometric observations were recorded at periodic intervals of 30DAS, 60DAS, 90 DAS and at harvest stage. Yield attributes parameters were recorded just before harvesting of crop. The crop was harvested on 10 November 2018 when about 80 per cent of the cobs turned yellowish and grains became hard and then tied in the labelled bundles. The sun dried weight of bundles was recorded. The cobs were removed from the plants, dried and threshed with hand 
operated maize sheller. Thus grain yield of each plot was recorded.

\section{Results and Discussion}

\section{Growth character}

The plant height recorded at 30,60, 90 and at harvest was statistically analyzed and furnished in (Table.1 and fig.1). Plant height differed significantly due to different treatments at all stages of crop growth. The plant height was found to increase progressively with advancement in growth of the crop up to harvest. At 30 DAS, among the treatment, the plant height $(34.0 \mathrm{~cm})$ was obtained with application of entire treatment of $100 \% \mathrm{RDF}+25 \%$ Vermicompost $+25 \%$ $\mathrm{FYM}+25 \mathrm{~kg} \mathrm{ZnSo}_{4}\left(\mathrm{~T}_{9}\right)$ which was on at par with the application of $100 \% \mathrm{RDF}+50 \%$ Vermicompost $+50 \%$ FYM $\left(\mathrm{T}_{10}\right) 50 \% \mathrm{RDF}+$ $25 \%$ Vermicompost $+25 \%$ FYM $+25 \mathrm{~kg}$ $\mathrm{ZnSo}_{4}\left(\mathrm{~T}_{7}\right)$ which was significantly superior over the other treatments. The effect of Vermicompost, FYM and chemical fertilizer in combination was more pronounced with the advancement of crop growth indicating better effect on plant height of maize. It might be attributed to improved fertility status of the soil through microbial and better utilization of plant nutrients by maize. Organic manures especially vermicompost supply nutrients to plant roots in balanced amount and stimulate growth, increase organic matter content of the soil including the "hemic substances" that affect nutrient accumulation and promote root growth which lead to better growth of maize plants resulting in taller plants. Similar were the results report the findings of Gosavi et al., (2006), Kumar et al.,(2005) and Ravi et al.,(2012). While shortest plant height (20.7 $\mathrm{cm})$ were observed with the application of $50 \% \mathrm{RDF}\left(\mathrm{T}_{2}\right)$ which was found to be on par with the application of with $100 \% \operatorname{RDF}\left(\mathrm{T}_{1}\right)$, $50 \% \mathrm{RDF}+\mathrm{FYM}\left(\mathrm{T}_{4}\right)$ and $50 \% \mathrm{RDF}$ + Vermicompost $\left(\mathrm{T}_{6}\right)$ respectively. Almost similar trend was observed at 60,90 DAS and at harvest.

Significantly higher Leaf area index was recorded with the application of $100 \% \mathrm{RDF}+$ $25 \%$ Vermicompost $+25 \%$ FYM $+25 \mathrm{~kg}$ $\mathrm{ZnSo}_{4}\left(\mathrm{~T}_{9}\right)$. However, it remained at par with $100 \%$ RDF $+50 \%$ Vermicompost $+50 \%$ FYM $\left(\mathrm{T}_{10}\right)$ and $50 \% \mathrm{RDF}+25 \%$ Vermicompost $+25 \% \mathrm{FYM}+25 \mathrm{~kg} \mathrm{ZnSo}_{4}$ $\left(\mathrm{T}_{7}\right)$. The beneficial effect of organic manures on leaf area index might be due to synthesis of certain phytohormones and vitamins and more interception of solar radiation and synthesis of more chlorophyll which resulted in higher leaf area index in maize. Similar results has also been reported by Kannan et al. (2013). While the treatment of $50 \%$ RDF $\left(\mathrm{T}_{2}\right)$ had results were lower.

Data pertaining to Dry matter accumulation is one of the important parameters reflecting the growth of a crop, is a prerequisite for higher yields, which indicated other biosynthetic process associated during the development sequences. The total dry matter production at harvest differed significantly among various treatments. The maximum total dry matter accumulation was observed with application of $100 \% \mathrm{RDF}+25 \%$ Vermicompost $+25 \%$ $\mathrm{FYM}+25 \mathrm{~kg} \mathrm{ZnSo}_{4}\left(\mathrm{~T}_{9}\right)$ and it was at par with the treatments $100 \% \mathrm{RDF}+50 \%$ Vermicompost $+50 \%$ FYM $\left(\mathrm{T}_{10}\right)$ and $50 \%$ $\mathrm{RDF}+25 \%$ Vermicompost $+25 \%$ FYM + $25 \mathrm{~kg} \mathrm{ZnSo}_{4}\left(\mathrm{~T}_{7}\right)$ significantly superior to rest of the treatments. Significantly higher dry matter accumulation in fertilizer treated plots might be due to greater solubility and accelerated release of nitrogen besides providing favorable rhizosphere for maize to utilize higher quantum of nutrients. Increased dry matter accumulation in vermicompost and FYM treated plots might be attributed due to the continuous steady release of nutrients which might have enabled the leaf area duration to extend, thus favoring the plants to 
increase the photosynthetic rate which in turn, could have led to higher accumulation of dry matter. Similar results were reported by Grazia et al., (2003), Arun Kumar et al. (2007) and Sanjiv and James (2010). While the lowest dry matter accumulation was recorded under the $50 \% \mathrm{RDF}\left(\mathrm{T}_{2}\right)$.

The highest CGR is observed at $100 \% \mathrm{RDF}+$ $25 \%$ Vermicompost $+25 \%$ FYM $+25 \mathrm{~kg}$
$\mathrm{ZnSo}_{4}$. while minimum $\mathrm{CGR}$ was recorded under 50\% RDF. In general Crop growth rate in the early stages due to the absence of vegetation and low percentage of light absorption is lower, but with the rapid increases in the rate of plant growth that occurs because the level of development of leaves and thus absorption of solar radiation increases. Similar result also reported bySabriet al.,(2000).

Table.1 Effect of integrated nutrient management on growth component of Kharif maize (Zea mays L.)

\begin{tabular}{|c|c|c|c|c|}
\hline Treatments & $\begin{array}{l}\text { Plant Height } \\
\text { (cm) } 90 \text { DAS }\end{array}$ & $\begin{array}{l}\text { Leaf area } 90 \\
\text { DAS }\end{array}$ & $\begin{array}{l}\text { Plant dry weight } \\
\text { (g) } 90 \mathrm{DAS}\end{array}$ & 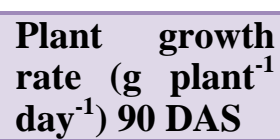 \\
\hline $\mathrm{T}_{1}-100 \% \mathrm{RDF}$ & 125.0 & 2.75 & 45.8 & 0.428 \\
\hline $\mathrm{T}_{2}-\mathbf{5 0 \%} \mathrm{RDF}$ & 117.3 & 2.01 & 37.3 & 0.378 \\
\hline 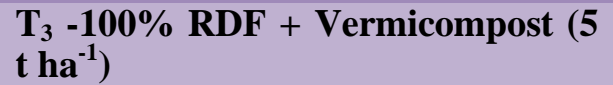 & 141.0 & 3.98 & 63.7 & 0.775 \\
\hline $\begin{array}{l}\mathrm{T}_{4}-50 \% \mathrm{RDF}+\text { Vermicompost (5 t } \\
\left.\mathrm{ha}^{-1}\right)\end{array}$ & 139.3 & 3.21 & 58.3 & 0.700 \\
\hline $\mathrm{T}_{5}-100 \% \mathrm{RDF}+\mathrm{FYM}\left(12.5 \mathrm{tha}^{-1}\right)$ & 140.3 & 3.54 & 62.7 & 0.764 \\
\hline $\mathrm{T}_{6}-50 \% \mathrm{RDF}+\mathrm{FYM}\left(12.5 \mathrm{t} \mathrm{ha}^{-1}\right)$ & 137.0 & 3.12 & 56.6 & 0.664 \\
\hline $\begin{array}{l}\mathrm{T}_{7}-50 \% \mathrm{RDF}+25 \% \text { Vermicompost } \\
\left(5 \mathrm{t} \mathrm{ha}^{-1}\right)+25 \% \text { FYM }\left(12.5 \mathrm{t}^{-\mathrm{ha}^{-1}}\right) \\
+25 \mathrm{~kg} \mathrm{ZnSo}_{4}\end{array}$ & 148.3 & 4.21 & 83.0 & 1.176 \\
\hline $\begin{array}{l}\mathrm{T}_{8}-50 \% \text { RDF }+50 \% \text { Vermicompost } \\
\left(5 \mathrm{t} \mathrm{ha}^{-1}\right)+ \\
50 \% \text { FYM }\left(12.5 \mathrm{t} \mathrm{ha}^{-1}\right)\end{array}$ & 144.0 & 4.02 & 78.7 & 1.116 \\
\hline $\begin{array}{l}\mathrm{T}_{9}-100 \% \mathrm{RDF}+25 \% \text { Vermicompost } \\
\left(5 \mathrm{t} \mathrm{ha}^{-1}\right)+25 \% \text { FYM }\left(12.5 \mathrm{t} \mathrm{ha}^{-1}\right)+ \\
25 \mathrm{~kg} \mathrm{ZnSo}_{4}\end{array}$ & 159.7 & 4.89 & 93.0 & 1.317 \\
\hline $\begin{array}{l}T_{10-100 \% \text { RDF }}+50 \% \text { Vermicompost } \\
\left(5 \mathrm{tha}^{-1}\right)+50 \% \text { FYM }\left(12.5 \mathrm{tha}^{-1}\right)\end{array}$ & 154.3 & 4.67 & 88.7 & 1.252 \\
\hline S. $\operatorname{Em}( \pm)$ & 2.8 & 0.7 & 5.3 & 5.6 \\
\hline C.D $(P=0.05)$ & 8.3 & 2.2 & 15.8 & 16.5 \\
\hline
\end{tabular}


Table.2 Effect of integrated nutrient management on grain, stover yield and Harvest index of maize (Zea mays L.)

\begin{tabular}{|c|c|c|c|}
\hline Treatments & $\begin{array}{l}\text { Kernel yield } \\
\text { (quintal ha }^{-1} \text { ) }\end{array}$ & $\begin{array}{l}\text { Stover yield } \\
\text { (quintal ha') }\end{array}$ & Harvest index (\%) \\
\hline $\mathrm{T}_{1}-100 \% \mathrm{RDF}$ & 43.3 & 115.2 & 27.30 \\
\hline $\mathrm{T}_{2}-\mathbf{5 0 \%} \mathrm{RDF}$ & 31.4 & 101.2 & 23.69 \\
\hline $\begin{array}{l}T_{3}-100 \% \quad \text { RDF } \\
\text { Vermicompost }\left(5 \mathrm{t} \mathrm{ha}^{-1}\right)\end{array}+$ & 60.2 & 139.5 & 29.97 \\
\hline $\begin{array}{l}\mathrm{T}_{4} \quad-50 \% \quad \mathrm{RDF} \\
\text { Vermicompost }\left(5 \mathrm{t} \mathrm{ha}^{-1}\right)\end{array}+$ & 56.3 & 133.3 & 29.54 \\
\hline $\begin{array}{l}T_{5}-100 \% \text { RDF + FYM }(12.5 \\
\left.t h^{-1}\right)\end{array}$ & 59.2 & 137.0 & 30.19 \\
\hline $\begin{array}{l}T_{6}-50 \% \text { RDF + FYM }(12.5 \\
\left.t \text { ha }^{-1}\right)\end{array}$ & 54.2 & 129.7 & 29.27 \\
\hline $\begin{array}{l}\mathrm{T}_{7}-50 \% \text { RDF }+25 \% \\
\text { Vermicompost }\left(5 \mathrm{t} \mathrm{ha}^{-1}\right)+ \\
25 \% \text { FYM }\left(12.5 \mathrm{tha}^{-1}\right)+25 \\
\mathrm{~kg} \mathrm{ZnSo}_{4}\end{array}$ & 64.2 & 146.6 & 30.45 \\
\hline $\begin{array}{l}\mathrm{T}_{8}-50 \% \text { RDF }+50 \% \\
\text { Vermicompost }\left(5 \mathrm{t} \mathrm{ha}^{-1}\right)+ \\
50 \% \text { FYM }\left(12.5 \mathrm{tha}^{-1}\right)\end{array}$ & 62.5 & 143.0 & 30.42 \\
\hline $\begin{array}{l}\mathrm{T}_{9}-100 \% \text { RDF }+25 \% \\
\text { Vermicompost }\left(5 \mathrm{t} \mathrm{ha}^{-1}\right)+ \\
25 \% \text { FYM }\left(12.5 \mathrm{t} \mathrm{ha}^{-1}\right)+25 \\
\mathrm{~kg} \mathrm{ZnSo}_{4}\end{array}$ & 71.3 & 153.7 & 31.40 \\
\hline $\begin{array}{l}\mathrm{T}_{10}-100 \% \text { RDF }+50 \% \\
\text { Vermicompost }\left(5 \mathrm{t} \mathrm{ha}^{-1}\right)+ \\
50 \% \text { FYM }\left(12.5 \mathrm{tha}^{-1}\right)\end{array}$ & 68.2 & 148.7 & 31.30 \\
\hline S. Em & 6.24 & 9.2 & 0.95 \\
\hline C.D ( $(P=0.05)$ & 18.4 & 27.2 & 2.83 \\
\hline
\end{tabular}

\section{Kernel yield}

In the present investigation the grain yield was significantly influence of integrated nutrient management treatments in maize. The highest grain yield (71.3 q ha $\left.{ }^{-1}\right)$ was obtained with the application of entire treatments $100 \% \mathrm{RDF}+25 \%$ Vermicompost + $25 \% \mathrm{FYM}+25 \mathrm{~kg} \mathrm{ZnSo}_{4}\left(\mathrm{~T}_{9}\right)$ which was on par with $100 \% \mathrm{RDF}+50 \%$ Vermicompost + $50 \%\left(\mathrm{~T}_{10}\right), 50 \% \mathrm{RDF}+25 \%$ Vermicompost $+25 \% \mathrm{FYM}+25 \mathrm{~kg} \mathrm{ZnSo}_{4} \quad\left(\mathrm{~T}_{7}\right)$ and significantly superior to other treatments. There was an increase of $30 \%$ more yield in best treatment $\mathrm{T}_{9} \quad(100 \%$ RDF +
$25 \%$ Vermicompost $+25 \%$ FYM $+25 \mathrm{~kg}$ $\left.\mathrm{ZnSO}_{4}\right)$ when compared to that of $\mathrm{T}_{2}(50 \%$ $\mathrm{RDF}$ ) which recorded the lowest grain yield $\left(31.4 \mathrm{qha}^{-1}\right)$.

The increase in yield under these treatments was because of favorable influence of nutrient application on the growth and yield attributes of maize. The improvement in grain yield under treatments involving organic fertilizer vermicompost and FYM might be due to the improvement in soil physico-chemical properties (viz., $\mathrm{pH}$, bulk density, infiltration rate and microbial biomass carbon) and optimum availability of nutrients and organic 
carbon which acted as the growth and yield enhancing characters of maize crop. Further the grain yield of maize mainly depends upon the final plant population and yield of individual plant, the latter in turn depends upon the number of cobs per plant and the weight of grains per cob which resulted in higher grain yield in maize. Similar results were also reported by Khadtare et al., (2006),Gosavi et al., (2009), Keerthi et al., (2013).

\section{Stover yield}

The stover yield of maize almost similar trend in Stover yield was observed as it was noticed in grain yield of maize. The highest strove yield (153.7 $\mathrm{q} \mathrm{ha}^{-1}$ ) was obtained with the application of entire treatments $100 \% \mathrm{RDF}+$ $25 \%$ Vermicompost $+25 \%$ FYM $+25 \mathrm{~kg}$ $\mathrm{ZnSo}_{4}\left(\mathrm{~T}_{9}\right)$ which was on par with $100 \% \mathrm{RDF}$ $+50 \%$ Vermicompost $+50 \%$ (T10), $50 \%$ $\mathrm{RDF}+25 \%$ Vermicompost $+25 \% \mathrm{FYM}+$ $25 \mathrm{~kg} \mathrm{ZnSo}_{4}\left(\mathrm{~T}_{7}\right)$ and significantly superior to other treatments. While the lowest Stover yield ( $101.2 \mathrm{q} \mathrm{ha}^{-1}$ ) was recorded with $50 \%$ RDF $\left(\mathrm{T}_{2}\right)$. The result are in close accordance with those reported by Rani et al., (2013).Sanjiv, K.V and Pitchai, J. (2010).

\section{Harvest index}

As regarded harvest index it was not influenced markedly due to different treatments (Table 12). The highest harvest index (31.40) was obtained under the application of entire treatments $100 \% \mathrm{RDF}+$ $25 \%$ Vermicompost $+25 \%$ FYM $+25 \mathrm{~kg}$ $\mathrm{ZnSo}_{4}\left(\mathrm{~T}_{9}\right)$ which was on par with $100 \% \mathrm{RDF}$ $+50 \%$ Vermicompost $+50 \%$ (T10), $50 \%$ $\mathrm{RDF}+25 \%$ Vermicompost $+25 \% \mathrm{FYM}+$ $25 \mathrm{~kg} \mathrm{ZnSo}_{4}\left(\mathrm{~T}_{7}\right)$ Excellent growth and development of maize plant under higher nutrient environment during critical period of crop growth might have resulted in higher harvest index under these treatments, while
$50 \%$ RDF resulted in the lowest value of harvest index (21.96). These findings are in agreement with the findings obtained by Graiziaet al., (2003), Katarkiet al., (2004).

Based on the findings of the present investigation, it can be inferred that the application of FYM and vermicompost along with chemical fertilizer proved in significantly enhancing the growth attributes and yield. All the treatments showed significate influenced on growth and yield of maize. Form the present study it was observed that $100 \% \mathrm{RDF}+25 \%$ Vermicompost $+25 \%$ $\mathrm{FYM}+25 \mathrm{~kg} \mathrm{ZnSo}_{4}$ gave the best result. Our results indicated that, organic fertilizer can be a better supplement of inorganic fertilizer to produce better growth and yield of maize.

\section{References}

Ghaffari, A., Ali, A., Tahir, M., Waseem, M., and Ayub, M. (2011). Influence of Integrated nutrients on growth, yield and quality of maize (Zea mays L.). American journal of plant science. 263269.

Gundlur, S.S., Patil, P.L., Rajkumara, S., Ashoka, $\mathrm{P}$ and Neelankantha, J.K. (2015). Influence of integrated nutrients management on yield on yield and uptake of nutrients by maize and soil fertility under irrigated condition in vertisol. Karnataka journal of agriculture science. 28 (2):172-175.

Gosavi,S.P., Chavan, S.A and Bhagat,S.B. 2006.Effect of fertilizer and level of FYM on yield quality and nutrient uptake of sweet corn(Zea mays Lsaccharata). Journal of soils and crops. 19(1):92-96.

Grazia, J.D., Tittonell, P.A., Germinara, D and Chiesa, A. 2003. Phosphorus and nitrogen fertilization in sweet corn (Zea mays L. saccharata). Spanish Journal of Agricultural Research. 1(2): 103-107. 
Kannan, R.L., Dhivya, M., Abinaya, D., Lekshmi, R.K and Kumar, S.K. (2013). Effect of integrated nutrient management on soil fertility and productivity in maize. Bullentin of Environment, Pharmacology and life sciences. 2(8):61-67.

Kataraki, N. G., Desai, B.K and Pujari, B.T.2004. Integrated nutrient management in irrigated maize. Karnataka Journal of Agricultural Sciences,17(1):1-4.

Khadtare, S.V., Patel, M.V., Jadha, J.D and Mokashi, D.D. (2006). Effect of vermicompost pon yield and economics of sweet corn. Journal of soil and Crops. 16(2):401-406.

Keerthi, S., UpendraRoa, A., Ramana, A.V and Tejeswara, R.K. (2013). Effect of nutrient management on cob yield, protein content, NPK uptake by sweet corn and post- harvest $\mathrm{N}, \mathrm{P}_{2} \mathrm{O}_{5}$ and $\mathrm{K}_{2} \mathrm{O}$
International journal of advanced biological research. 3(4) 553-555.

Rani ,U.I., Padmaja, G and Chandrasekhar Rao, P.(2013). Integrated effect of organic manures and inorganic ertilizers on soil urease activity and yield of maize-spinach cropping system. Journal of Research. ANGRAU 41(2) 42-45.

Ravi, N., Basavarajappa, R., Chandrashekar, C.P., Harlapur, S.I., Hosamani, M.H., and Manjunath, M.V. (2012). Effect of integrated nutrient management on growth and yield of quality protein maize (Zea mays L.) Karnataka Journal of Agriculture science 25(3):395-396.

Sanjiv, K.V and Pitchai, J. (2010). Effect of various sources of organic manures on yield and yield attribute of irrigation maize (Zea mays L.) Super 900M. An Asian Journal of Soil Science .5(2):399401.

\section{How to cite this article:}

Iniya Ponmozhi, C.N., Rabindra Kumar, YasinAbrar Baba and GantaMallikarjuna Rao. 2019. Effect of Integrated Nutrient Management on Growth and Yield of Maize (Zea mays L.). Int.J.Curr.Microbiol.App.Sci. 8(10): 2675-2681. doi: https://doi.org/10.20546/ijcmas.2019.811.306 